Proc. Estonian Acad. Sci. Geol., 1995, 44, 2, 73-86

\title{
CONFACIES DIFFERENTIATION AND UPPER MIDDLE ORDOVICIAN CORRELATION IN THE BALTOSCANDIAN BASIN
}

\author{
Valdar JAANUSSON
}

Naturhistoriska Riksmuseet, Sektionen för Paleozoologi (Department of Palaeozoology, Swedish Museum of Natural History), Box 50007, S-10405 Stockholm, Sverige (Sweden)

Received 12 September 1994, accepted 20 October 1994

Abstract. It is suggested that the Ordovician belt with the distinctive North Estonian lithology and benthic fauna - the North Estonian Confacies Belt - does not extend as far to the west as previously believed. The considerable thickness of the postTremadocian Lower Ordovician sequence in the submarine South Bothnian district, revealed by borings, is comparable to that in the Jelgava depression of western Latvia, indicating that the Ordovician depositional history of the Baltoscandian basin is more complicated than has been assumed. The new term Haljala Stage is introduced for the portion of the upper Middle Ordovician sequence in the Baltoscandian basin that comprises the previous North Estonian Idavere and Jõhvi stages; the rank of the two latter units is reduced to substages. It is emphasized that the boundaries of biozones based on planktic organisms, such as conodonts, graptoloids and chitinozoans, seldom coincide with the levels at which benthic faunas change. A new species, Amplexograptus baltoscandicus n. sp., is described.

Key words: Ordovician, Baltoscandia, confacies, graptolites.

\section{INTRODUCTION}

During much of the Ordovician Period the benthic fauna of northern Estonia differed conspicuously from that of the adjacent belt to the west and south (Мянннль, 1966; Jaanusson, 1976; Jaanusson \& Bergström, 1980). In the Middle and Upper Ordovician the faunal differences between these major composite facies belts, which are referred to as "confacies belts" (Jaanusson, 1976), are so pronounced that the benthic fauna provides very few clues for regional correlation. This is especially true for the sequence from about the base of the Diplograptus multidens Zone upwards. For the upper part of the Middle Ordovician it has therefore been difficult to apply a uniform stage classification for much of the Baltoscandian basin.

The intention of this paper is to discuss some problems related to the boundaries between the confacies belts and to summarize the available evidence pertinent to the correlation of the upper part of the Middle Ordovician between the North Estonian and Central Baltoscandian Confacies Belts. A complicating factor is that in the latter belt the sequence is mostly poorly exposed and known mainly from borings. For this reason, in the Central Belt attention is focused on the Siljan district in Dalarna and on the Fjäcka section (Jaanusson \& Martna, 1948; Jaanusson, 1963, $1976,1982)$ in particular. The advantage of the Siljan district is that the sequence appears to be reasonably complete.

(C) Eesti TA Toimetised. Geoloogia, 1995 


\section{REMARKS ON BALTOSCANDIAN CONFACIES BELTS}

Confacies belt has proven to be a useful concept for classifying the composite spatial distribution of Ordovician lithofacies and faunas not only in the Baltoscandian region but also in the Appalachians (Jaanusson \& Bergström, 1980). In the former region new data have accumulated, mainly from borings, which must be integrated with the previously known evidence.

In Estonia, Põlma (Пылма, 1967) distinguished a transitional belt between the "Estonian and axial facies zones". The relation of the "transitional belt" to the concept of confacies belts requires some explanation. As defined by Põlma (Пылма, 1967), the transitional belt is characterized by an interlocking pattern of various lithofacies from these two main composite belts, and by the occurrence of some transitional lithologies. It is preponderantly a lithofacial concept and should preferably be referred to as "lithofacially transitional belt". The definition of a confacies belt is based on a combination of faunal and lithofacies characters (Jaanusson, 1976; Jaanusson \& Bergström, 1980), but the remarkable feature is the fairly abrupt change in much of the benthic fauna (in the case of the southern Appalachian belts even in the conodont fauna) at the boundary between some belts, even in the cases where a lithofacies is reasonably continuous from one belt to the other. The fauna is more sensitive to changes in environment than sedimentation and therefore the factors that cause differences in the fauna are not always distinctly reflected in the composition of the sediment. In southern Estonia the benthic fauna in much of the lithologically transitional belt (see, for example, Laeva boring; Мянниль, 1966, fig. 15) is still basically the same as in the Central Confacies. Based on faunal criteria, much of Põlma's "transitional belt" appears to belong to the Central Baltoscandian Confacies Belt.

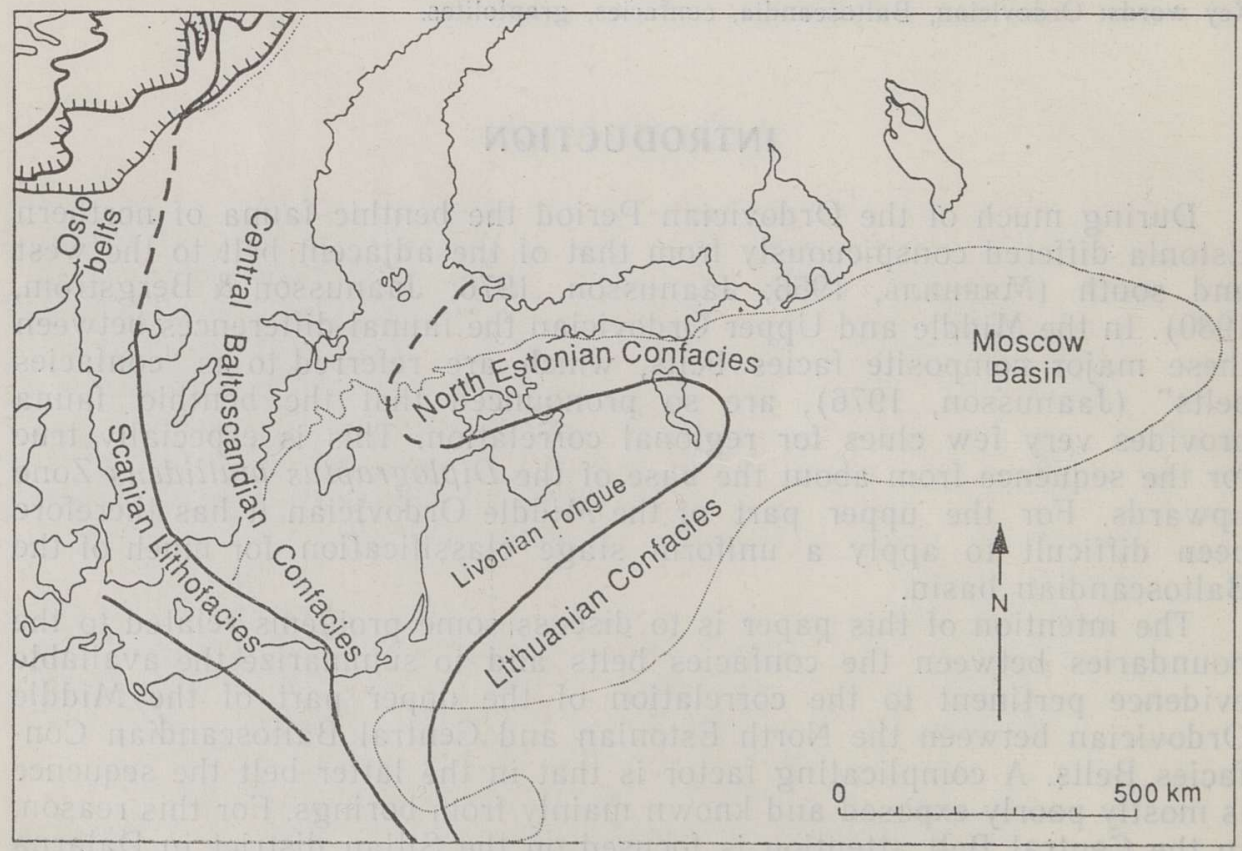

Fig. 1. Approximate boundaries between the post-Tremadoc Ordovician confacies belts in the Baltoscandian region. 
The boundaries between various Baltoscandian confacies belts are, of course, not so sharp and unequivocal as depicted on the modified version of the confacies map (Fig. 1). Transitional areas must exist also in the distribution of the benthic faunas but they are at present difficult to define. There was some spatial fluctuation of the boundaries in time but details are still unclear.

New data from borings in eastern Sweden have shown that the North Estonian Confacies Belt does not extend as far to the west as previously suggested (Мянниль, 1966, fig. 2; Jaanusson, 1976, text-fig. 7).

Southern Gotland (borings at Grötlingbo and När; Snäll, 1977; Grahn, 1982 ) is situated within the Central Baltoscandian Confacies Belt, both lithologically and faunally. The File Haidar boring on northern Gotland (Thorslund \& Westergård, 1938) is lithologically in several respects "transitional" but the benthic fauna (V. Jaanusson, unpublished data) appears to be predominantly that of the Central Belt. In the boring on Gotska Sandön the lithology of the Ordovician sequence is very similar to that of the File Haidar boring, but in the benthic fauna (V. Jaanusson, unpublished data) the influx of species that otherwise are restricted to the North Estonian Belt is somewhat more noticeable.

On the previous maps (Мянниль, 1966, fig. 2; Jaanusson, 1976, textfig. 7) the boundary between the North Estonian and Central Confacies belts was, conditionally, drawn within the submarine South Bothnian Cambro-Ordovician district (for the extent of the Ordovician submarine outcrop area of the district see Axberg \& Flodén, 1977; and Axberg, 1980, fig. 13). At that time the available information on the Ordovician sequence of the district was based solely on erratic boulders deposited by the continental glacier on adjacent land areas, especially in the provinces of Gästrikland and Uppland in east-central Sweden and on islands of the Aland Archipelago (Wiman, 1903, 1907). The faunal evidence from various boulders seemed to indicate an eastwards increasing influence from North Estonia. A boring at Finngrundet (Tjernvik \& Johansson, 1980; Löfgren, 1985), in the eastern part of the South Bothnian district, pierced most of the Lower Ordovician sequence and yielded unexpected results. The thickness of parts of the post-Tremadocian Lower Ordovician is considerable, $19 \mathrm{~m}$ for the Volkhov Stage and exceeding $20.8 \mathrm{~m}$ for the Kunda Stage (Tjernvik \& Johansson, 1980), comparable to the greatest thickness of these beds known elsewhere in the limestone sequence of the Baltoscandian basin (Jelgava depression in western Latvia; Мянниль, 1966, figs. 52, 53; Ульст et al., 1982, figs. 42,43). As in the Jelgava depression, the rock of these units is a red, argillaceous limestone. A re-examination of the faunal evidence from the erratic boulders showed that in the South Bothnian district the North Estonian influence was previously overestimated. The Middle Ordovician sequence of the district appears to be similar to that of the Siljan district, with regard to both lithology and fauna. Thus, the eastern boundary of the Central Belt was situated some, probably considerable, distance east and southeast of the Gulf of Bothnia. The location of the boundary is difficult to estimate since no Ordovician deposits are preserved on the mainland of Finland and between the Aland Archipelago and northern Estonia.

The classification of Männil (Мянниль, 1966) "Scanian Facial Zone" in terms of confacies presents difficulties. In the Lower and Middle Ordovician the characters of the belt are mainly those of a lithofacial unit in which the rock is preponderantly graptolitic shale. The belt includes a few relatively thin limestone units (Komstad and Skagen limestones) with a benthic fauna close to that of the Central Belt. Conversely, some graptolitic shale units (Töyen, Mossen, and Fjäcka shales) are widespread in the Central Belt. Higher up in the Upper Ordovician, above the Pleuro- 
graptus linearis Zone, the sequence of the Scanian region consists of mudstones (Jerrestad and Tommarp formations) with a varied shelly fauna, and then the region forms an extension of the Central Baltoscandian Confacies Belt, both lithologically and faunally. The change from graptolitic shale to a shelly facies (or to virtually barren mudstones) at about that level is not a feature specific to Scania and Bornholm but a comparable change takes place also in several other regions of the world where the graptolitic shale lithofacies extends into the Pleurograptus linearis Zone.

Lindholm (1991) emphasized that the belt of graptolitic shales from Scania over Hunneberg in Västergötland to the Oslo district represents a single depositional basin at least until the end of Arenig time. Above about the Hustedograptus teretiusculus Zone, the Oslo Region developed a different, fairly complicated pattern of composite facies belts (Bockelie, 1978) that do not include any shale lithofacies. The rocks of that age referred to as "shale" in the Oslo Region (such as in Arnestad and Venstöp formations) by Owen et al. (1990) represent mainly mudstones (non-fissile argillite), in some areas with an appreciable content of silt.

\section{THE STATUS OF THE IDAVERE AND JÖHVI STAGES}

The Idavere ("Itfer") Stage was distinguished by Schmidt (1881) in his basic classification of the Ordovician sequence in northern Estonia. The beds included in the stage were accessible to Schmidt only in a few small exposures in northeastern Estonia, above all in the quarry of the manorial estate of Idavere. The quarry was fairly extensive but shallow, became soon overgrown (Raymond, 1916, p. 198), and subsequently even its location was forgotten. The site of the former Idavere quarry was rediscovered only quite recently and previous difficulties in determining its location were explained (Сарв \& ПЫлма, 1989).

The difficulties in examining the original Idavere Beds in the field led to a misinterpretation of Schmidt's concept of the unit (Bekker, 1924, 1925; Öpik, 1927, 1930). The Idavere Beds were believed to constitute the upper portion of the Kukruse Stage or belong to a composite Kukruse-Idavere Stage, but in reality the Idavere Beds in Schmidt's sense were mostly included in the Jõhvi Stage (for a detailed historical review see PыымyсoKc, 1970 , pp. 184-187). A contributing factor to the misinterpretation may have been that Schmidt (1882) vastly overestimated the thickness of his Idavere Beds, reporting it to be $20-30$ feet.

On the basis of an examination of both old collections from the Idavere type locality and cores of some borings in northeastern Estonia, Jaanusson (1945) was able to clarify Schmidt's original concept of the Idavere Stage and to define the base of the stage at its former level. In the outcrop area of northeastern Estonia the thickness of the unit proved to be much less than previously believed, in the type area only some $1.5 \mathrm{~m}$ (see Пылма et al., 1988). Following a suggestion by Raymond (1916), it was proposed to increase the scope of the Idavere Stage by drawing the upper boundary somewhat higher, at the level of the appearance of the macrofauna characteristic of the Johvi Stage. The increase in the scope of the Idavere Stage was generally accepted but, for practical reasons, Männil (Мянниль, 1963) suggested that the stage boundary be drawn at a bentonite bed, some $1.5-2 \mathrm{~m}$ below the macrofaunal boundary.

Thus defined, the Idavere Stage is a useful unit for the North Estonian sequence (Рыbмyсокс, 1970), but outside the spatial range of the key bentonite bed, which moreover is not always easy to identify with certainty, the recognition of the upper boundary proved to be difficult (see also Männil, 1990, p. 17). The boundary does not coincide with a distinct 
change in either macro- or microfauna and it is situated within a lithologically uniform sequence. The ostracode fauna, in particular, does not change at that level (Пылма et al., 1988). The appearance of Amplexograptus cf. fallax Bulman (= A. baltoscandicus n. sp., described below) has been used for recognition of the boundary level (Мянниль, 1976) but the importance of this event for correlation appears to be limited. The appearance of a few macrofaunal species higher up in the Jöhvi Stage is not conspicuous; the level is difficult to determine, and it is not known whether all these species appear at the same level. For the Baltoscandian basin as a whole the usefulness of these two chronostratigraphic units (Idavere and Jõhvi stages) is therefore limited.

For the entire Baltoscandian basin a useful unit would be a stage which comprises, as substages, both the Idavere and Jōhvi units. For this reason it is here proposed to include the beds from the base of the Idavere Beds to the base of the Keila Stage in a single stage, the Haljala Stage. It is named for Haljala parish, where the type area of the Idavere Stage is situated and which comprises some of the outcrop area of the Jôhvi Substage (Сарв \& Пылма, 1989, fig. 1). The base of the Haljala Stage is defined as that of the Idavere Substage. In its type area the base of the substage is marked by a distinct discontinuity surface (Jaanusson, 1945), indicating a break in the sequence. Hints et al. (1993; see also Nõlvak \& Grahn, 1993) proposed therefore to define the boundary further southwards, in the Laeva region, as the base of the chitinozoan subzone of Armoricochitina granulifera which, according to Nõlvak and Grahn (1993, fig. 6), coincides with the top of Laufeldochitina stentor Zone. The top of the Haljala Stage coincides with the base of the Keila Stage.

The base of the Haljala Stage is slightly above the base of the conodont subzone of Baltoniodus gerdae (Мянниль, 1986). According to the evidence from conodonts (Bergström, 1971) and chitinozoans (Laufeld, 1967) the level of the base of the stage in the Fjäcka section of the Siljan district is approximately $6.5-7.0 \mathrm{~m}$ below the base of the complex of bentonite beds as defined by Jaanusson \& Martna (1948) and Jaanusson (1963). In that section the lithology is uniform across the stage boundary, but Männil (Мянниль, 1966) suggested the existence of a slight change in the benthic fauna at about that level. In a limestone sequence the level of a graptolite zone boundary is notoriously difficult to determine since biostratigraphically important graptolite species rarely occur together with index species of conodonts. Bergström (1971) suggested that the base of the Diplograptus multidens Zone as defined in the Scanian succession (Nilsson, 1977) is fairly close to the base of the Baltoniodus gerdae Subzone, and subsequently no evidence has come forth that would contradict this suggestion. According to Hughes (1989) D. multidens is a junior subjective synonym of $D$. foliaceus, but there is no need to change the name of the zone, provided that the name cannot be replaced by that of some other species that is more distinctive for the zone.

\section{BASE OF THE KEILA STAGE}

The base of the Keila Stage is defined (Jaanusson, 1948; Jaanusson \& Martna, 1948 , p. 192; Мянниль, 1958) as that of the so-called Main Bentonite Bed. It is the thickest bentonite bed, up to $0.45 \mathrm{~m}$ thick on northeastern Estonian mainland (Рыымусокс, 1970, fig. 46; Вингисаар, 1972, fig. 1), in the boundary region between the Jöhvi Substage and the Keila Stage.

In Sweden the thickest bentonite bed, up to $1.8 \mathrm{~m}$ thick on Kinnekulle in Västergötland, is termed the Big Bentonite Bed, and it defines the base 
of the Skagen Limestone (Jaanusson, 1964). A recent revision of the interpretation of the stratigraphy in some southeastern Estonian borings has revealed that beds which contain elements of the Skagen fauna but which were previously correlated with the Jöhvi Stage (Мянниль, 1966) are of Keilan age (R. Männil, pers. comm., 1988). This removes a serious discrepancy in previous correlations (Jaanusson, 1976) because now the biostratigraphic evidence also supports the suggestion (Мянниль, 1966; Вингисаap, 1972) that the thickest bentonite beds on both sides of the Baltic Sea are contemporaneous. Further support is provided by an identical "chemical fingerprint" for this K-bentonite across the Baltic Sea (Huff et al., 1992).

The Main Bentonite forms a most useful key horizon over a substantial area of the Baltoscandian basin. It is located at about the middle of the Arnestad Mudstone in the Oslo-Asker district of Norway (Hagemann \& Spjeldnaes, 1955), at the base of the Skagen Limestone in many districts of Sweden, in the upper part of the Sularp Mudstone in Scania (Bergström \& Nilsson, 1974; Nilsson, 1977), near the base of the Dicellograptus Shale as developed on the Island of Bornholm (Bergström \& Nilsson, 1974), and at the base of the Keila Stage in northern and western Estonia, western Ingria, and northwestern Latvia. It is interesting to note that according to current correlations it is not the Main Bentonite that has the widest extent toward southeast but beds which appear to belong to the complex of bentonite beds in the boundary region between the Idavere and Jõhvi substages. Thin bentonite beds of that complex reach as far as to central Lithuania (Сидаравичиене, 1979).

The Main Bentonite is slightly below the base of the Amorphognathus superbus Zone (S. M. Bergström, pers. comm., 1992). The level of the base of the Dicellograptus clingani Zone is situated somewhat higher, probably somewhere in the middle of the Skagen Limestone (Bergström \& Nilsson, 1974).

According to Huff et al. (1992) the Main Bentonite is the same as the Millbrig K-bentonite in eastern North America. In this case, according to them, the bed belongs to one of the largest, if not the largest, volcanic ash falls recorded in the Phanerozoic of the earth. Despite that, the effect of the volcanic event on faunas and floras was minimal, not least on probable planktic organisms such as graptoloids, conodonts, and chitinozoans (Huff et al., 1992, fig. 5).

Many benthic organisms are very susceptible to changes in the physical properties of the substrate upon or within which they are living. The extensive ash fall must have caused a marked change in these conditions over vast areas of the seafloor, affecting the environment especially for communities that were adapted to a comparatively coarse grained substrate. However, in Baltoscandia the change in the benthic fauna across the Main Bentonite is slight. It is more pronounced in the Central Baltoscandian Confacies Belt than in the North Estonian Belt, but in both belts a number of species cross the ash bed. Thus, despite of the vastness of the seafloor area covered with volcanic ash, the effect of the changed physical properties of the substrate on the benthic fauna was trifling.

The faunal change is best documented in ostracode faunas since information on vertical ranges of macrofossils, such as trilobites or brachiopods, is less exact. In the North Estonian Belt the ostracode assemblage, which consists of species appearing mainly in the Idavere Substage, continues with insignificant changes into the Keila Stage (Пылма et al., 1988, figs. 17, 26, 27). In the Central Baltoscandian Belt the proportion of immigrants above the Main Bentonite is larger (Jaanusson, 1976, fig. 9), as is the number of species not known to cross the ash bed, but the overall faunal change is still comparatively small, 


\section{CORRELATION OF THE BASE OF THE OANDU STAGE}

During Oanduan and Rakverean times the differences in the benthic faunas between the North Estonian Confacies Belt and the Central Baltoscandian Confacies Belt were especially conspicuous and the faunas provide very few clues for correlation. The level of the base of the Oandu Stage does not appear to coincide with a graptolite or conodont zonal boundary, and this contributes to the difficulty of correlating this level.

According to Männil (Мянниль, 1966) the base of the Oandu Stage corresponds most likely to that of the "Macrourus Limestone" (= Molda Topoformation; Jaanusson, 1973) in the Siljan district. This correlation is now known to be supported by ranges of some chitinozoan taxa, In Estonia, Desmochitina nodosa reaches the base of the Oandu Stage, and Spinachitina cervicornis (s. lato) to a slightly higher level (Nõlvak, 1990; Nõlvak \& Grahn, 1993; J. Nõlvak, pers. comm.). In the Siljan district both taxa have a similar range relative to the base of the Molda Topoformation (Laufeld, 1967). At the base of both the Oandu Stage (Рыымycокс, 1970, table 17; Пылма et al., 1988, figs. 28, 36, 37) and the Molda Topoformation (Jaanusson, 1976, fig. 9, 1982, fig. 7) the change in the benthic faunas is pronounced although the composition of the faunas is quite different.

Further support for the correlation of the base of the Oandu Stage with that of the Molda Topoformation is provided by the occurrence of Toxochasmops extensus in the lower Oanduan Hirmuse and Saku beds of northern Estonia (Chasmops macrourus in Рымусокс (1953), identification subsequently (Рыымусокс, 1970) corrected to $C$. extensus). In the Siljan district this species appears at the base of the Molda Topoformation (Jaanusson, 1982, fig. 7).

\section{DISCUSSION}

The introduction of the concept of Haljala Stage makes it possible to extend a workable chronostratigraphic classification in the carbonate facies of the Baltoscandian basin from the Kukruse Stage to the Oandu Stage. Kukruse, Haljala, and Keila stages appear to be recognizable with a sufficient precision over much of the basin. The base of the Oandu Stage seems to be fairly well defined over much of the region but because of the uncertainties pertaining to the correlation of the base of the Rakvere Stage, the application of the concept of Oandu Stage is at present difficult outside northern Estonia and Ingria.

In the Baltoscandian basin the biostratigraphic information is more detailed than in the Ordovician sequences elsewhere, even if much additional work remains to be done. The precision of the data is especially good for vertical ranges of ostracodes, conodonts, chitinozoans, and graptoloids, and also for several groups of macrofossils. Information is now accumulating also on acritarchs (Uutela \& Tynni, 1991) and inarticulate brachiopods (Holmer, 1986, 1989).

An interesting result is that, as shown in Fig. 2, the levels of important changes in the probable planktic graptolite and conodont faunas mostly do not coincide with the levels at which the benthic fauna changes, suggesting that the factors that affected planktic faunas were largely different from those that caused changes in the regional benthic faunas (Jaanusson, 1976). The spatial range of planktic species is mostly considerable, although in the Ordovician Period, in which biogeographic differentiation is more pronounced than in most other Phanerozoic periods, also planktic faunas display a distinct provincialism. Ordovician benthic faunas, on the 
other hand, were biogeographically differentiated into numerous provinces, and the spatial range of individual species is mostly limited. The factors that caused changes in the widespread planktic faunas and floras did not necessarily affect regional environmental conditions of the seafloor. Changes in the regional conditions, in turn, are not always reflected in the succession of organisms with a semicosmopolitan distribution. Thus, diachronism of the changes in local benthic and widespread planktic faunas may have been a rule rather than an exception.

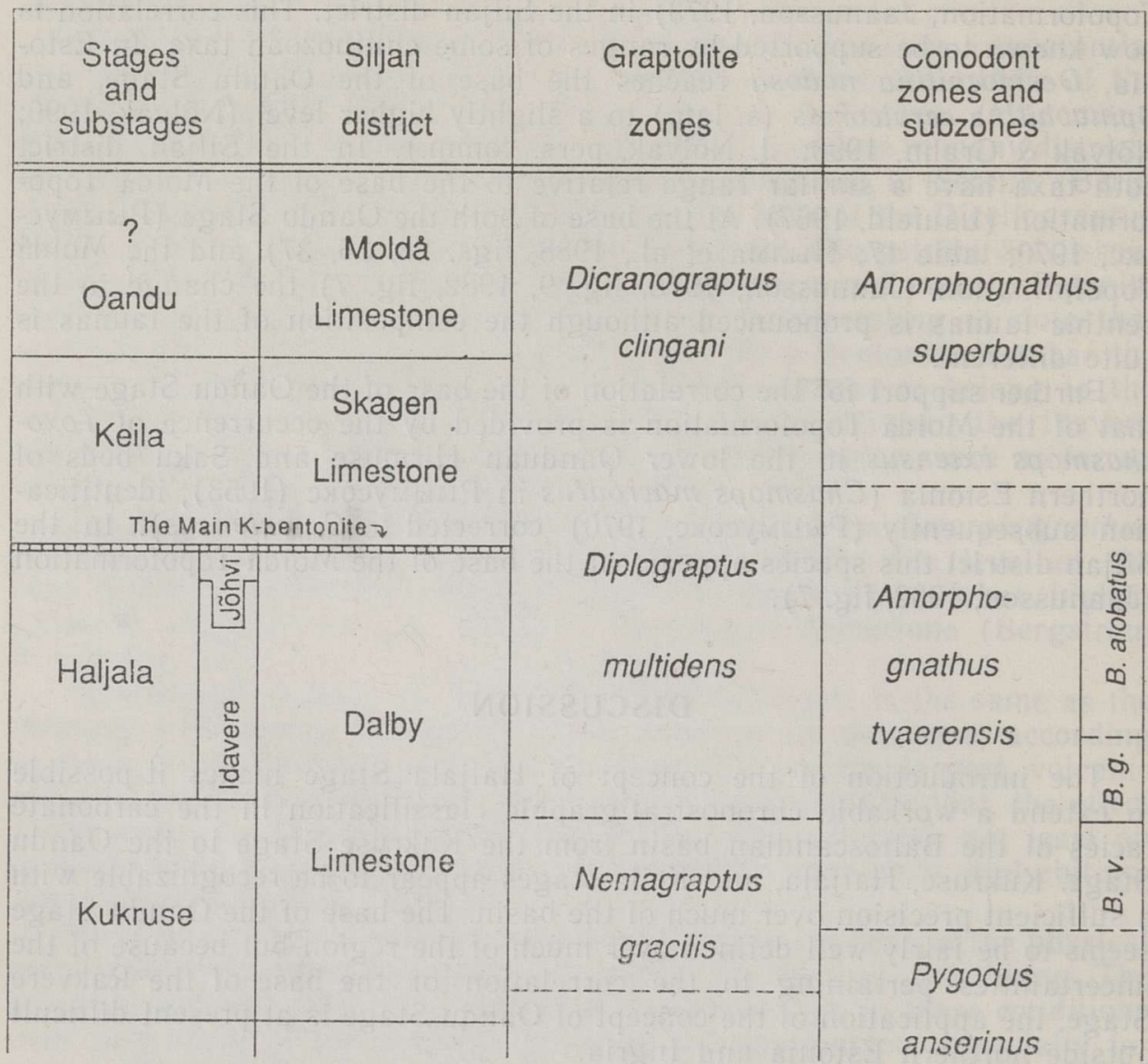

Fig. 2. Correlation of the upper Viruan sequence in the Siljan district, Dalarna, with North Estonian stages and with the graptolite and conodont zonation. In the Siljan district the thickness of the probable equivalents to the Jöhvi Substage is apparently inconsiderable.

\section{APPENDIX}

Amplexograptus baltoscandicus n. sp. (Fig. 3)

1932 Climacograptus sp.: Bulman, pp. 16-17, pl. 3, figs. 21-23. (non pl. 3 , figs. $24-25$ and $28-32=$ Climacograptus skagensis Jaanusson \& Skoglund, 1963; non pl. 3, figs. 26-27 = Pseudoclimacograptus sp. indet.).

1960 Amplexograptus? n. sp.: Jaạussson, p. 351, 
1962 Amplexograptus fallax n. sp. (partim): Bulman, p. 463 (non text-fig. $2=$ A. leptotheca Bulman, 1946)

1963 Amplexograptus cf. fallax Bulman: Jaanusson \& Skoglund, pp. $348-350$, fig. 3 .

1976 Amplexograptus cf. fallax Bulman: Мянниль, figs. 4, 5 (range in borings).

?1977 Amplexograptus cf. fallax Bulman: Nilsson, pp. 39-40, table 1 (range in a boring).

Holotype. Rhabdosome RM Cn 1516 from the Jõhvi Substage of Põõsaspea (Spitham) in northwestern Estonia (Fig. 3; Bulman, 1932, pl. 3, figs. $21-22)$.

Diagnosis. Rhabdosome increasing in width from $0.9-1.1 \mathrm{~mm}$ at th $2^{1}-2^{2}$ to $1.2-1.3 \mathrm{~mm}$ at th $6^{1}-6^{2}$. Supragenicular wall concave, distinctly inclined relative to the rhabdosome axis, its height equal to, or only slightly greater than, that of apertural excavation. Supragenicular wall of th $2^{1}$ normally distinctly longer than that of th $3^{1}$. Antivirgellar spines paired, th $1^{1}$ with a subapertural spine. Aseptate.

Discussion. Bulman (1962) considered the Estonian specimens that he had previously figured $(1932$, pl. 3, figs. $21-23)$ to belong to his new species A. fallax based on specimens from Scotland. Jaanusson \& Skoglund (1963) followed Bulman's identification, but only conditionally and with considerable doubt. On the basis of a revision of the holotypes and additional syntypes of $A$. fallax and A. leptotheca Bulman, 1946, Hughes
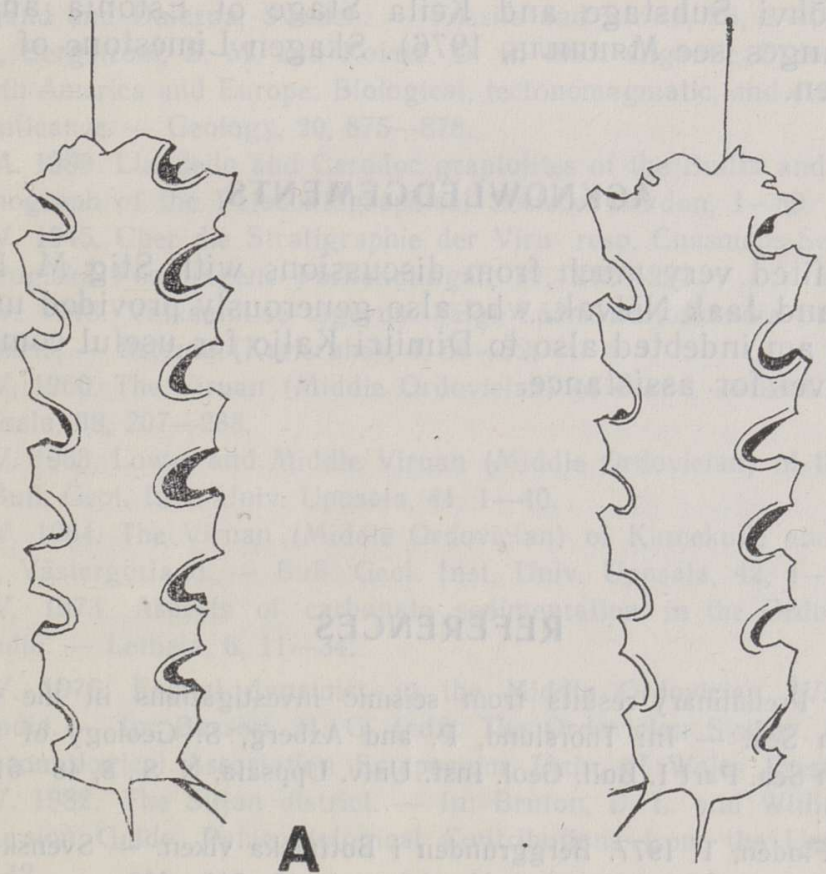

Fig. 3. Amplexograptus baltoscandicus n. sp. Drawing of the holotype, based on the figures in Bulman (1932, pl. 3, figs. 21, 22). Northern Estonia, Põõsaspea (Spitham); A obverse and B reverse aspect. Jõhvi Substage. $\times 20$, 
(1989, pp. 56-58) concluded that these two species are subjective synonyms. It is now clear that the Baltoscandian specimens that were previously identified as $A$. cf. fallax belong to a different species.

A. baltoscandicus n. sp. is adequately figured by Bulman (1932, pl. 3, figs. $21-23$ ) and Jaanusson \& Skoglund (1963, fig. 3A-D), who also provide a description of the species. It differs from $A$. leptotheca in comparatively higher apertural excavations and a stronger inclination of the supragenicular wall even on distal thecae (Bulman, 1932, pl. 3, fig. 23). The supragenicular wall of th $2^{1}$ is normally conspicuously higher than that of the next thecae. It is strange that in his "diagrammatic reconstructions" of A. leptotheca Bulman (1946, text-figs. 22, 23) figured the proximal end with paired antivirgellar spines even if none of the figured specimens (Bulman, 1946, pl. 4) show this feature. The specimens from the Shelve inlier also have only a single antivirgellar spine (Hughes, 1989 , p. 58). In Bulman's (1962) description of A. fallax antivirgellar spines are not mentioned, and his figures (1962, text-fig. 2 A-B) show only a single spine. A. baltoscandicus has consistently paired antivirgellar spines.

Specimens from the Platteville Limestone of Wisconsin, identified as A. maxwelli Decker, 1935, have paired antivirgellar spines and resemble A. baltoscandicus also in some other features (Walker, 1953; Crowther, 1981, pl. 8, fig. 1, text-fig. 17). However, in that species the supragenicular wall is almost parallel to the axis of the rhabdosome and the rhabdosome is slightly narrower.

The identification of specimens from the upper Dicranograptus clingani Zone of the Koängen core in Scania, which Nilsson (1977) referred to A. cf. fallax, requires further study.

Occurrence. Jõhvi Substage and Keila Stage of Estonia and western Latvia (for ranges see Мянниль, 1976). Skagen Limestone of Västergötland in Sweden.

\section{ACKNOWLEDGEMENTS}

I have profited very much from discussions with Stig $M$. Bergström, Ralf Männil, and Jaak Nõlvak, who also generously provided unpublished information. I am indebted also to Dimitri Kaljo for useful comments and to Harry Mutvei for assistance.

\section{REFERENCES}

Axberg, S. 1980. Preliminary results from seismic investigations in the southwestern Bothnian Sea. - In: Thorslund, P. and Axberg, S. Geology of the Southern Bothnian Sea. Part I. Bull. Geol. Inst. Univ. Uppsala, N. S., 8, 48-61 (vol. issued in 1980).

Axberg, S. and Flodén, T. 1977. Berggrunden i Bottniska viken. - Svenska Havsforskningsföreningen (Meddelanden, Norrköping), 12, 218-229.

Bekker, H. 1924. Mõned uued andmed Kukruse lademe stratigraafiast ja faunast. Stratigraphical and paleontological supplements on the Kukruse Stage of the Ordovician rocks of Eesti (Estonia). [In Estonian and English.] - Acta et Commentationes Universitatis Tartuensis, A6, 1-20.

Bekker, H. 1925. Lühike ülevaade Eesti geoloogiast, - In: Eesti, 
Bergström, S. M. 1971. Conodont biostratigraphy of the Middle and Upper Ordovician of Europe and eastern North America. - Geol. Soc. America Memoir, 127, $83-162$.

Bergström, S. M. and Nilsson, R. 1974. Age and correlation of the Middle Ordovician bentonites on Bornholm. - Bull. Geol. Soc. Denmark, 23, 27-48.

Bockelie, J. F. 1978. The Oslo Region during the Early Palaeozoic. - In: Ramberg, J. B. and Neumann, E.-R. (eds.). Tectonics and Geophysics of Continental Rifts. D. Reidel, Dordrecht, 195-202.

Bulman, O. M. B. 1932. On the graptolites prepared by Holm. 1. Certain 'Diprionidian' graptolites and their development. Arkiv för Zoologi, 22A, 1-111.

Bulman, O. M. B. 1946. A monograph of the Caradoc (Balclatchie) graptolites from limestones in Laggan Burn, Ayrshire. Part II. - Monograph of the Palaeontographical Society. London, $43-58$.

Bulman, O. M. B. 1962. On the genus Ample.rograptus Lapworth, Elles and Wood. Geol. Mag., 99, 459-467.

Crowther, P. R. 1981. The fine structure of graptolite periderm. - Special Papers in Palaeontology, 26, 1-119.

Grahn, Y. 1982. Caradocian and Ashgillian Chitinozoa from the subsurface of Gotland. Sveriges Geologiska Undersökning C788, 1-66.

Hagemann, F. and Spjeldnaes, N. 1955. Notes on bentonites (K-betonites) from the Oslo-Asker district. - Norsk Geologisk Tidsskrift, 35, 29-51.

Hints, L., Meidla, T. and Nõlvak, J. 1993. On the boundary stratotypes of the Ordovician regional stages in the East Baltic. - In: Abstracts, 2nd Baltic Stratigraphic Conference. Vilnius, 25.

Holmer, L. E. 1986. Inarticulate brachiopods around the Middle-Upper Ordovician boundary in Västergötland. - Geologiska Föreningens Förhandlingar, 108, 97126.

Holmer, L. E. 1989. Middle Ordovician phosphatic inarticulate brachiopods from Västergötland and Dalarna, Sweden. - Fossils and Strata, 26, 1-172.

Huff, W. D., Bergström, S. M. and Kolata, D. R. 1992. Gigantic Ordovician ash fall in North America and Europe: Biological, tectonomagmatic, and event-stratigraphical significance. - Geology, 20, 875-878.

Hughes, R. A. 1989. Llandeilo and Caradoc graptolites of the Builth and Shelve inliers. Monograph of the Palaeontographical Society. London, 1-89.

Jaanusson, V. 1945. Uber die Stratigraphie der Viru- resp. Chasmops-Serie in Estland. Geologiska Föreningens Förhandlingar, 67, 212-224.

Jaanusson, V. 1948. Vulkaanilise tegevuse jälgi Lääne-Baltoskandia ordoviitsiumi settekivimeis. - Estonia (Karlsruhe), 4, 50-52.

Jaanusson, V. 1960. The Viruan (Middle Ordovician) of Oland. - Bull. Geol. Inst. Univ. Uppsala, 38, 207-288.

Jaanusson, V. 1963. Lower and Middle Viruan (Middle Ordovician) of the Siljan district. - Bull. Geol. Inst. Univ. Uppsala, 41, 1-40.

Jaanusson, V. 1964. The Viruan (Middle Ordovician) of Kinnekulle and northern Billingen, Västergötland. - Bull. Geol. Inst. Univ. Uppsala, 42, 1-73.

Jaanusson, V. 1973. Aspects of carbonate sedimentation in the Ordovician of Baltoscandia. - Lethaia, 6, 11-34.

Jaanusson, V. 1976. Faunal dynamics in the Middle Ordovician (Viruan) of BaltoScandia. - In: Bassett, M. G. (ed.). The Ordovician System. Proceedings of a Palaeontological Association Symposium, Univ. of Wales Press, 301-326.

Jaanusson, V. 1982. The Siljan district. - In: Bruton, D. L. and Williams, S. H. Field Excursion Guide. Palaeontological Contributions from the Univ. of Oslo, 279, $15-42$.

Jaanusson, V. and Bergström, S. M. 1980. Middle Ordovician faunal spatial differentiation in Baltoscandia and the Appalachians. - Alcheringa, 4, 89-110.

Jaanusson, V. and Martna, J. 1948. A section from the upper Chasmops Series to the Lower Tretaspis Series at Fjäcka rivulet in the Siljan area, Dalarne. - Bull. Geool, Inst. Univ. Uppsala, 32, 183-193, 
Jaanusson, V. and Skoglund, R. 1963. Graptoloids from the Viruan (Ordovician) Dalby and Skagen Limestones of Västergötland. - Geologiska Föreningens Förhandlingar, 85, 341-357.

Laufeld, S. 1967. Caradocian Chitinozoa from Dalarna, Sweden. - Geologiska Föreningens Förhandlingar, 89, 275-349.

Lindholm, K. 1991. Ordovician graptolites from the Early Hunneberg of southern Scandinavia. - Palaeontology, 34, 283-327.

Löfgren, A. 1985. Early Ordovician conodont biozonation at Finngrundet, south Bothnian Bay, Sweden. - Bull. Geol. Inst. Univ. Uppsala, N. S., 10, 115-128.

Männil, R. 1990. The Ordovician of Estonia. - In: Kaljo, D. and Nestor, H. (eds.). Field Meeting Estonia 1990. An Excursion Guidebook. Tallinn, 11-20.

Nilsson, R. 1977. A boring through Middle and Upper Ordovician strata at Koängen in western Scania, southern Sweden. - Sveriges Geologiska Undersökning C733.

Nõlvak, J. 1990. Ordovician chitinozoans. - In: Kaljo, D. and Nestor, H. (eds.). Field Meeting Estonia 1990. An Excursion Guidebook. Tallinn, 77-79.

Nõlvak, J. and Grahn, Y. 1993. Ordovician chitinozoan zones from Baltoscandia. - Review of Palaeobotany and Palynology, 79, 245-269.

Öpik, A. 1927. Beiträge zur Kenntnis der Kukruse Stufe in Eesti II. - Acta et Commentationes Universitatis Tartuensis, A12, 1-35.

Opik, A. 1930. Brachiopoda Protremata der estländischen ordovizischen Kukruse-Stufe. Acta et Commentationes Universitatis Tartuensis, A17, 1-261.

Owen, A. W., Bruton, D. L., Bockelie, J. F. and Bockelie, T. G. 1990. The Ordovician successions of the Oslo Region, Norway. - Norges Geologiske Undersökelse, Special Publication, 4, 1-54.

Raymond, P. E. 1916. The correlation of the Ordovician strata of the Baltic basin with those of eastern North America. - Bulletin of the Museum of Comparative Zoology at Harvard College, 56, 179-286.

Schmidt, F. 1881. Revision der ostbaltischen silurischen Trilobiten I, Phacopiden, Cheiruriden und Encrinuriden. - Mémoires de l'Académie Impériale des Sciences, Ser. $7,30,1-238$.

Schmidt, F. 1882. On the Silurian (and Cambrian) strata of the Baltic provinces of Russia, as compared with those in Scandinavia and the British Isles. - Quarterly J. Geol. Soc. for November 1882, 514-536.

Snäll, S. 1977. Silurian and Ordovician bentonites of Gotland (Sweden). - Stockholm Contributions in Geology, 31.

Thorslund, P. and Westergård, A. H. 1938. Deep boring through the Cambro-Silurian at File Haidar, Gotland. - Sveriges Geologiska Undersökning C415, 1-56.

Tjernvik, T. E. and Johansson, J. V. 1980. Description of the upper portion of the drillcore from Finngrundet in the South Bothnian Bay. - Bull. Geol. Inst. Univ. Uppsala, N. S., 8, 173-204.

Uutela, A. and Tynni, R. 1991. Ordovician acritarchs from the Rapla borehole, Estonia. Geol. Surv. Finland, Bull., 353, 1-135.

Walker, M. 1953. The development of a diplograptid from the Platteville Limestone. Geol. Mag., 90, 1-16.

Wiman, C. 1903. Studien über das nordbaltische Silurgebiet 1. - Bull. Geol. Inst. Univ. Upsala, 6, 12-76.

Wiman, C. 1907. Studien über das nordbaltische Silurgebiet 2. - Bull. Geol. Inst. Univ. Upsala, 8, 73-168.

Вингисаар П. 1972. О распространении главного слоя метабентонита (d; XXI) в среднем ордовике Балтоскандии. - Изв. АН ЭССР. Хим. Геол., 21, 1. $62-70$.

Мянниль Р. 1958. Основные черты стратиграфии кейлаского горизонта (DII, ордовик) в Эстонии. - Изв. АН ЭССР. Сер. техн. и физ.-матем. наук, 7, 3, $235-246$.

Мянниль Р. 1963. Вопросы сопоставления ордовикских отложений Эстонии и Ленинградской области. - Тр. Ин-та геол. АН ЭССР, 13, 3-40. 
Мянниль Р. 1966. История развития Балтийского бассейна в ордовике. Валгус, Таллинн.

Мянниль Р. 1976. Распределение граптолоидей в карбонатных отложениях ордовика Прибалтики. - In: Кальо Д. Л., Корень Т. Н. (ed.). Граптолиты и стратиграфия. Валгус, Таллинн, 105-118.

Мянниль Р. 1986. Стратиграфия кукерситоносных отложений $\mathrm{C}_{\mathrm{I}} \mathrm{b}-\mathrm{C}_{\text {III. }}$ - In: Пуура В. (еd.). Строение сланценосной толщи Прибалтийского бассейна горючих сланцев-кукерситов. Валгус, Таллинн, $11-24$.

Пылма Л. 1967. О переходной полосе между северной и осевой фациальными зонами ордовика Прибалтики. - Изв. АН ЭССР. Хим. Геол., 16, 3, 272275.

Пылма Л., Сарв Л., Хинтс Л. 1988. Литология и фауна типовых разрезов карадокского яруса в Северной Эстонии. АН ЭССР, Таллинн.

Рыымусокс А. 1953. Новые данные о трилобитах рода Chasmops из ордовика Эстонской ССР. - Юбилейный сборник Общества естествоиспытателей. Таллинн, $397-413$.

Рымусокс А. 1970. Стратиграфия вируской и харьюской серий (ордовик) Северной Эстонин. Валгус, Таллинн.

Сарв Л., Пылма Л. 1989. Характеристика стратотипического обнажения среднеордовикского ндавереского горизонта. - Изв. АН ЭССР. Геол., 38, 1 , $14-22$.

Сидаравичене Н. 1979. Прослеживание кейлаского горизонта среднего ордовика в разрезах Восточной Литвы по остракодам. - Изв. АН ЭССР. Геол., 28, 4, $133-139$.

Ульст Р. Ж., Гайлите Л. К., Яковлева В. И. 1982. Ордовик Латвии. Зинатне, Рига.

\section{BALTOSKANDIA BASSEINI KONFAATSIESED JA KESKORDOVIITSIUMI ULAOSA KORRELATSIOON}

\section{Valdar JAANUSSON}

Ordoviitsiumi väga iseloomulike kivimite ja bentilise fauna kivististe vöönd, mida käsitatakse Põhja-Eesti konfaatsiesena, ei levi nii kaugele läände, nagu seni arvati. Botnia lahe lõunaosas puurimisel tuvastatud Tremadoci-järgse alamordoviitsiumi kihi suur paksus, mis on võrreldav nende kivimite paksusega Jelgava nõos Lääne-Lätis, näitab, et sedimentatsioon oli Baltoskandia basseini ordoviitsiumis seniarvatust keerukam. On tehtud ettepanek nimetada Haljala lademeks Baltoskandia keskordoviitsiumi ülaosa, mida seni käsitati Idavere ja Jõhvi lademena, ning kaht viimast pidada alamlademeiks. On märgitud, et planktilistel organismidel, nagu konodontidel, graptoliitidel ja kitinosoadel baseeruvate biotsoonide piirid langevad harva kokku bentilise fauna mutumise tasemetega. On kirjeldatud uut liiki Amplexograptus baltoscandicus. 


\section{КОНФАЦИАЛЬНАЯ ДИФФЕРЕНЦИАЦИЯ И КОРРЕЛЯЦИЯ ВЕРХОВ СРЕДНЕГО ОРДОВИКА БАЛТОСКАНДИИ}

\section{Валдар ЯАНУССОН}

Зона со специфическими ордовикскими отложениями и бентосной фауной, рассматриваемая в качестве Северо-Эстонской конфации, распространяется не столь далеко на запад, как предполагалось до сих пор. Бурением в южной части Ботнического залива установлены толщи пост-тремадокского ордовика, сравнимые по мощности с теми же отложениями в Елгавском прогибе в Западной Латвии. Это указывает на более сложную историю седиментации в ордовике Балтоскандии, чем считалось до настоящего времени. Предлагается новое название хальялаский горизонт - для верхов среднего ордовика Балтоскандии, ранее рассматриваемых в качестве идавереского и йыхвиского горизонтов; последние переводятся в ранг подгоризонта. Отмечается, что границы биозон, проводимые на основе планктонных организмов (конодонтов, граптолитов и хитинозой), редко совпадают с уровнями, на которых изменяется состав бентосной фауны. Описывается новый вид Amplexograptus baltoscandicus. 